EKONOMI BISNIS DAN KEWIRAUSAHAAN

Vol. VIII, No. 1, Januari 2019

\title{
NILAI PERUSAHAAN REAL ESTATE
}

\author{
Kun Ismawati \\ Fakultas Ekonomi Universitas Surakarta \\ email: kun.ismawati@gmail.com
}

\begin{abstract}
The purpose of the study is to determine the effect of investment policies, funding policies, and dividend policies on the value of real estate companies listed in the Indonesia Stock Exchange either partially or simultaneously. Data used in this research is secondary data obtained from the company's financial statements, as many as 42 companies from 2012-2014 period. There were 126 data obtained and analyzed with t test, $\mathrm{F}$ test, coefficient of determination test, and multiple linear regression test. The conclution of the research were investment policies, funding policies, and dividend policies affect the value of real estate companies listed in the Indonesia Stock Exchange either partially or simultaneously.
\end{abstract}

Keywords: investment, funding, dividend and corporate value.

\section{PENDAHULUAN}

\section{Latar Belakang Masalah}

Nilai perusahaan banyak menjadi bahan kajian para peneliti. Sartono (2005: 12) berpendapat bahwa para stakeholder sangat mengharapkan kemakmuran perusahaannya. Hal ini bisa mereka lihat dari nilai perusahaan yang semakin naik seiring waktu. Kemakmuran yang semakin besar yang diperoleh para pemegang saham inilah, salah satu yang dianggap mampu menaikkan nilai perusahaan. Ukuran kinerja manajemen perusahaan juga bisa diketahui dari nilai perusahaan yang dikelola. Keahlian manajer dalam mengelola dana investor ini menjadi tolok ukur investor untuk memberi kepercayaan lebih pada perusahaan, berdasarkan peningkatan harga saham yang dialami perusahaan (Sawir, 2005: 47).

Kebijakan berupa keputusan pendanaan menjadi keputusan penting lain dalam peningkatan nilai perusahaan. Dana bisa diperoleh manajer dari internal maupun eksternal perusahaan. Dana dari dalam bisa berasal dari laba yang ditahan, sedangkan dari luar perusahaan dapat mengandalkan dari utang dan modal sendiri dari saham. Atmaja (2005) menyatakan bahwa komposisi utang dan modal sendiri harus dipertimbangkan sehingga keputusan finansial terkait hal-hal tersebut dapat dibuat dengan tepat. Hal ini didukung pendapat Ozumomba et al (2016) yang menyatakan bahwa laba ditahan-pun bisa menjadi sumber pembiayaan dan kegiatan reinvestasi yang diharapkan dapat lebih memaksimalkan nilai perusahaan.

Indikator kesuksesan investasi dapat diketahui dari pendapatan investasi (return) 
EKONOMI BISNIS DAN KEWIRAUSAHAAN

Vol. VIII, No. 1, Januari 2019

yang harus lebih besar dari tingkat risiko (risk) yang harus ditanggung perusahaan. Peningkatan harga saham akan diraih bila perusahaan dapat memaksimalkan return yang diperolehnya dari keputusan investasi tersebut. Tingkat return yang tinggi dianggap mampu meningkatkan harga saham sehingga secara otomatis meningkatkan nilai perusahaan (Jogiyanto, 2005: 71).

Perusahaan real estate dipilih sebagai sumber data dalam penelitian ini karena perkembangan bisnis bidang ini sedang meningkat tajam. Investor perlu mempertimbangkan return dan risk dari kegiatan investasi yang akan dilakukan. Return tinggi menunjukkan kinerja perusahaan. Kehati-hatian perlu diterapkan oleh semua pihak. Hasnawati (2017: 2) mengingatkan bahwa pertumbuhan pesat yang terjadi dalam suatu perusahaan biasanya mengharapkan profitabilitas yang tinggi sehingga butuh dana cukup besar untuk membiayai investasi mereka. Hal ini justru menyebabkan keuangan perusahaan kurang likuid serta tertundanya dividen, karena kegiatan terkonsentrasi pada investasi.

Penelitian ini ingin menggali pengaruh kebijakan investasi, kebijakan pendanaan, dan kebijakan dividen terhadap nilai perusahaan. Sisi lain menyoroti bahwa kontinuitas pembagian dividen juga dianggap mampu mendongkrak nilai perusahaan. Perbedaan kepentingan antara manajemen perusahaan dan investor sebagai pemilik perusahaan inilah yang bisa menimbulkan agency conflict yang harus diantisipasi.

\section{Tujuan Penelitian}

Tujuan penelitian ini untuk menentukan apakah terdapat pengaruh signifikan kebijakan investasi, kebijakan pendanaan dan kebijakan dividen terhadap nilai perusahaan real estate di Bursa Efek Indonesia secara parsial dan secara simultan?

\section{Kajian Teori}

1. Kebijakan investasi (price earning ratio/ PER)

Wijaya, et al (2010) berpendapat bahwa kebijakan investasi adalah kebijakan penanaman modal pada aktiva perusahaan dengan tujuan untuk memperoleh keuntungan di masa mendatang. Kebijakan ini diproksikan dengan price earning ratio (PER) yang merupakan rasio harga penutupan saham dengan laba per lembar saham (earning per share/ EPS).

2. Kebijakan pendanaan (Debt to Equity Ratio/DER)

Kebijakan pendanaan merupakan kebijakan yang terkait dengan pemilihan utang atau modal sebagai sumber pendanaan. Penggunaannya ditujukan untuk membuat para pemilik perusahaan semakin makmur. Pemilihan keputusan sumber dana ini menggunakan rasio debt to equity, yakni rasio perhitungan penggunaan utang dibandingkan dengan menggunakan modal.

3. Kebijakan Dividen (Dividend Payout Ratio) 
EKONOMI BISNIS DAN KEWIRAUSAHAAN

Vol. VIII, No. 1, Januari 2019

Kebijakan dividen merupakan kebijakan terkait pendapatan, apakah akan diberikan pada para stakeholder dalam bentuk dividen, atau justru ditahan sebagai dana internal perusahaan. Kebijakan ini diproksikan dengan dividend payout ratio (DPR).

4. Nilai Perusahaan (Price Book Value/PBV)

Persepsi yang diberikan investor pada perusahaan dihubungkan dengan harga saham merupakan nilai suatu perusahaan. Nilai perusahaan akan tinggi bila perusahaan tersebut memiliki harga saham yang tinggi pula. Price book value (PBV) menjadi ukuran nilai pasar uang terhadap manajemen dan perusahaan itu sendiri.

5. Theory of the firm

Teori ini adalah teori untuk memaksimumkan kekayaan atau nilai perusahaan (value of the firm). Nilai perusahaan yanng maksimal berarti mampu membawa kemakmuran bagi para stakeholder dengan maksimal. Nilai perusahaan dianggap sebagai harga yang mampu dibayar calon pembeli bila perusahaan suatu saat dijual (Husnan, 2005).

7. Bird in the Hand Theory

Teori ini berpendapat bahwa investor akan lebih suka pada dividen dibandingkan capital gain karena memberikan tingkat kepastian yang lebih tinggi. Likuiditas merupakan hal utama dalam kebijakan pembayaran dividen. Semakin besar komposisi kas dan likuiditas perusahaan, semakin besar kemampuan perusahaan untuk membayar dividen (Sartono, 2008). Berkaitan dengan leverage/ utang, kebijakan dividen an struktur utang berkorelasi dengan modal (Abbas, et al, 2016). Muthusany \& John (2010) juga berpendapat serupa, bahwa perusahaan dengan leverage tinggi cenderung rendah dalam membayar dividen. Hal ini sangat menjadi perhatian para stakeholder, sehingga perusahaan harus sangat berhati-hati dalam pengelolaannya.

\section{Kerangka Pemikiran}

Kerangka pemikiran penelitian ini sebagai berikut:

Variabel bebas

Variabel

terikat

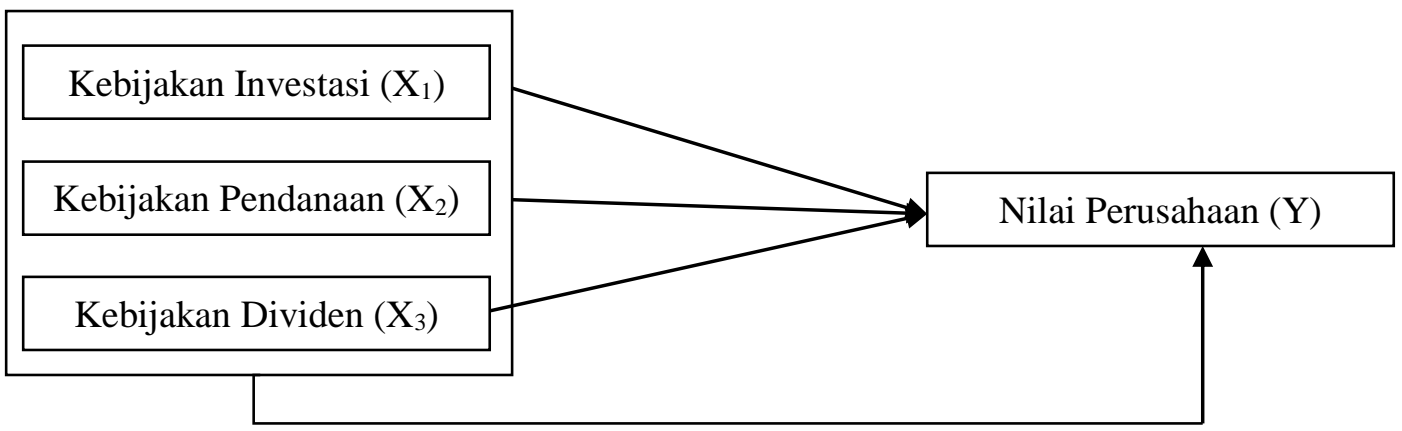

\section{HIPOTESIS}

Gambar 1. Kerangka Pemikiran 
EKONOMI BISNIS DAN KEWIRAUSAHAAN

Vol. VIII, No. 1, Januari 2019

Hipotesis penelitian ini sebagai berikut: "Diduga kebijakan investasi, kebijakan pendanaan dan kebijakan deviden berpengaruh signifikan terhadap nilai perusahaan real real estatedi Bursa Efek Indonesia secara parsial dan simultan".

\section{METODOLOGI PENELITIAN}

Penelitian ini merupakan penelitian kuantitatif. Metode yang digunakan dalam pengumpulan data penelitian adalah studi pustaka pada laporan keuangan perusahaan real estate yang listed di Bursa Efek Indonesia periode tahun 2012 hingga 2014, dan melibatkan sebanyak 126 data. Data penelitian ini merupakan data sekunder. Uji statistik dalam penelitian meliputi uji t, uji F, uji regresi linier berganda, dan uji koefisien determinasi.

\section{HASIL PENELITIAN DAN PEMBAHASAN}

Tabel I

Hasil Statistik Deskriptif

Statistics

\begin{tabular}{|c|c|c|c|c|c|}
\hline & & $\begin{array}{c}\text { Nilai } \\
\text { Perusahaan }\end{array}$ & $\begin{array}{c}\text { Kebijakan } \\
\text { Investasi }\end{array}$ & $\begin{array}{l}\text { Kebijakan } \\
\text { Pendanaan }\end{array}$ & $\begin{array}{c}\text { Kebijakan } \\
\text { Deviden }\end{array}$ \\
\hline \multirow[t]{2}{*}{$\mathrm{N}$} & Valid & 126 & 126 & 126 & 126 \\
\hline & Missing & 0 & 0 & 0 & 0 \\
\hline mean & & 1230.98579 & 50.42661 & .84790 & 87.30375 \\
\hline Std. & & 9115.764208 & 116.223905 & 1.077861 & 138.214351 \\
\hline \multicolumn{6}{|l|}{ Deviation } \\
\hline Minimum & & .000 & .000 & .024 & .000 \\
\hline Maximum & & 79634.487 & 733.333 & 10.628 & 657.541 \\
\hline
\end{tabular}

Sumber: Print Out SPSS, Desember 2015

Tabel 2

Hasil Uji Regresi Linier Berganda

Coefficients $^{\mathbf{a}}$

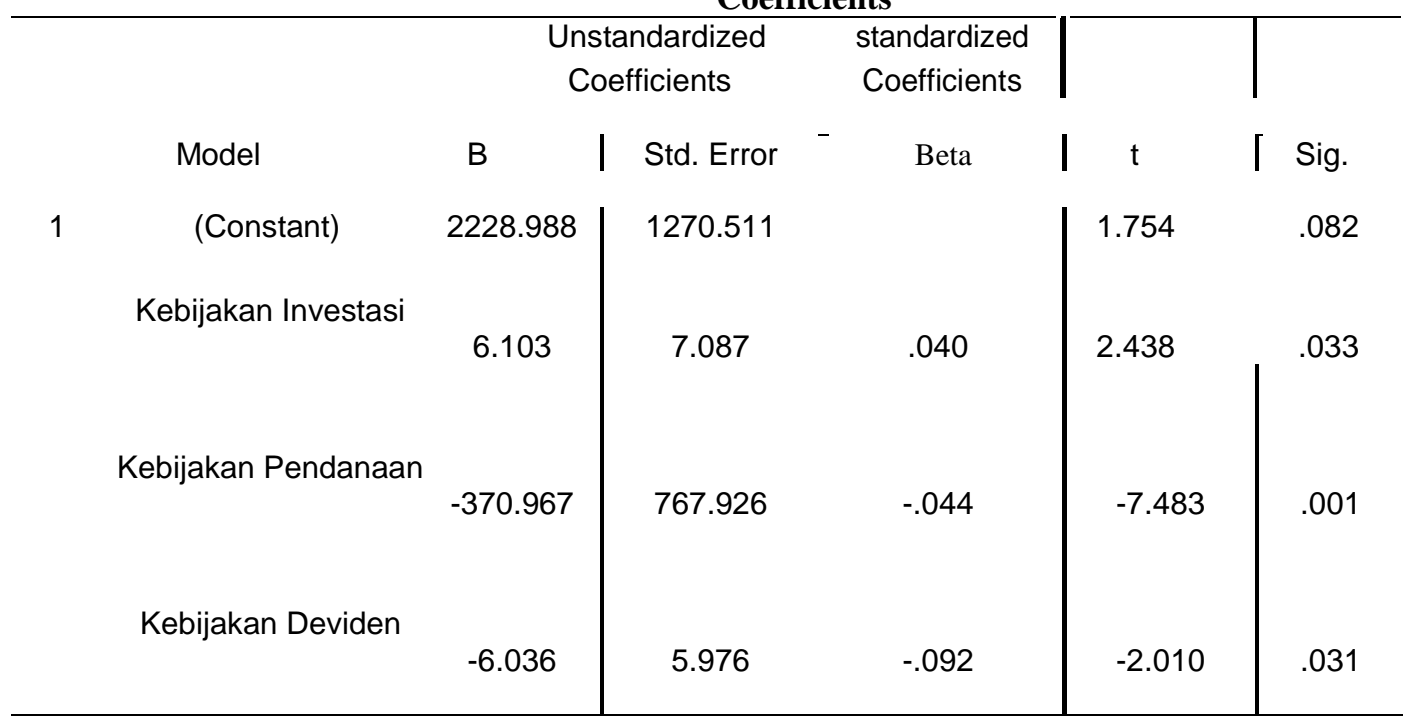

a. Dependent Variable: Nilai Perusahaan

Sumber: Hasil Olah Data, Desember 2015 


\section{EKONOMI BISNIS DAN KEWIRAUSAHAAN}

Vol. VIII, No. 1, Januari 2019

Pengujian terhadap hipotesis 1 diperoleh hasil bahwa kebijakan investasi yang diproksikan dengan price earning ratio (PER) terbukti memiliki pengaruh signifikan pada nilai perusahaan real estate di Bursa Efek Indonesia. Hal ini diketahui dari nilai $\mathrm{t}$ hitung $>\mathrm{t}$ tabel $(2,438>1,797)$ dimana $p$-value memiliki angka lebih kecil dari 0,05, sehingga Ho ditolak dan $\mathrm{H}_{1}$ diterima. Hipotesis 1 pada penelitian ini yang menyatakan bahwa: "kebijakan investasi berpengaruh signifikan terhadap nilai perusahaan real estate di Bursa Efek Indonesia" adalah terbukti kebenarannya. Kebijakan investasi berpengaruh positif dan signifikan pada nilai perusahaan. Nilai perusahaan akan semakin bagus jika kebijakan investasi dalam perusahaan semakin baik.

Pengujian terhadap hipotesis 2 diperoleh hasil bahwa kebijakan pendanaan yang dilihat dari debt earning ratio (DER) terbukti berpengaruh signifikan terhadap nilai perusahaan real estate di Bursa Efek Indonesia. Hal ini dapat dilihat dari nilai -t hitung $<-t$ tabel $(-7.483<-1,797)$ dengan $p$-value lebih kecil dari 0,05, berarti Ho ditolak dan $\mathrm{H}_{2}$ diterima. Hipotesis 2 penelitian ini "Kebijakan pendanaan berpengaruh signifikan terhadap nilai perusahaan real estate di Bursa Efek Indonesia" terbukti kebenarannya. Kebijakan pendanaan yang dilihat dari debt equity ratio berpengaruh negatif signifikan terhadap nilai perusahaan. Hal ini menunjukkan bahwa makin tinggi rasio kebijakan pendanaan berupa debt equity ratio, yakni perbandingan jumlah utang yang makin besar dibandingkan jumlah ekuitas pada perusahaan bisa menurunkan nilai perusahaan tersebut.

Pengujian hipotesis 3 diperoleh hasil bahwa kebijakan dividen yang dilihat dari deviden payout ratio (DPR) memiliki pengaruh signifikan terhadap nilai perusahaan real estate di Bursa Efek Indonesia. Bukti bisa dilihat dari angka $-\mathrm{t}$ hitung $<-\mathrm{t}$ tabel ($2,010<-1,797)$ dimana $p$-value angkanya lebih kecil dari 0,05 , berarti Ho ditolak dan $\mathrm{H}_{3}$ diterima. Hal ini menunjukkan bahwa kebijakan dividen berpengaruh signifikan terhadap nilai perusahaan. Hipotesis 3 penelitian yang menyatakan bahwa "Kebijakan dividen berpengaruh signifikan terhadap nilai perusahaan real estate di Bursa Efek Indonesia" terbukti kebenarannya. Kebijakan dividen yang diproksikan dengan dividen payout ratio (DPR) berpengaruh negatif signifikan terhadap nilai perusahaan. Rasio kebijakan pendanaan yang makin tinggi di perusahaan akan bisa menurunkan nilai perusahaan.

\section{PENUTUP}

\section{Kesimpulan}

Hasil analisis terhadap data penelitian menghadirkan kesimpulan bahwa secara parsial kebijakan investasi berpengaruh signifikan terhadap nilai perusahaan, kebijakan pendanaan berpengaruh negatif signifikan terhadap nilai perusahaan, dan kebijakan dividen berpengaruh negatif signifikan terhadap nilai perusahaan. Hasil analisis data secara simultan ketiga variabel bebas memiliki pengaruh yang signifikan terhadap variabel terikat; yakni variabel kebijakan investasi, kebijakan pendanaan, dan kebijakan dividen berpengaruh signifikan terhadap nilai perusahaan. 
EKONOMI BISNIS DAN KEWIRAUSAHAAN

Vol. VIII, No. 1, Januari 2019

Hal ini mendukung hasil penelitian Setiani (2013) yang menyatakan bahwa kebijakan investasi dan kebijakan pendanaan berpengaruh signifikan terhadap nilai perusahaan.

\section{Saran}

Penelitian lain dimasa datang dapat dilakukan mengenai implikasi penilaian terhadap dividen payout ratio (DPR). Penelitian juga bisa diperluas pada jenis perusahaan yang berbeda, serta dengan menambah jumlah data amatan. Kinerja keuangan lain bisa ditambahkan untuk mengetahui faktor yang mempengaruhi nilai perusahaan.

\section{DAFTAR PUSTAKA}

Atmaja, Lukas Setia. 2005. Manajemen Keuangan. Penerbit Andi, Yogyakarta.

Jogiyanto, Hartono. 2005. Teori Portofolio dan Analisis Investasi. BPFE UGM, Yogyakarta.

Hasnawati, Sri. 2017. Kebijakan Dividen di Bursa Efek Indonesia pada Perusahaan Kelompok LQ 45. Jurnal Manajemen Universitas Tarumanegara. Vol. 21 No. 1 (2017). ISSN No. 1410-3583.

Muthusamy, K \& John. SF. 2010. "Leverage, Growth and Profitability as Determinants of Dividend Payout Ratio-Evidence From Indian Paper Industry”. Asian Journal of Business Management Studies. Vol. 1 (1): 26-30. ISSN 2222-1387. IDOSI Publications.

Ozumomba C. N, Anichebe, A.S., Okoye P.V.C. 2016. The Effect of Dividend Policies on Wealth Maximization-a study of Some Selected Plcs. Journal Cogent Business \& Management. Vol. 3.

Sartono, Agus. 2005. Manajemen Keuangan Teori dan Aplikasi. BPFE, Yogyakarta.

2008. Manajemen Keuangan Teori dan Aplikasi. Yogyakarta. BPFE.

Sawir, Agnes. 2005 Analisis Kinerja Keuangan dan Perencanaan Keuangan Perusahaan. Gramedia Pustaka Utama, Jakarta.

Setiani, Rury. 2013. Pengaruh Keputusan Investasi, Keputusan Pendanaan, Dan Tingkat Suku Bunga Terhadap Nilai Perusahaan Pada Perusahaan Otomotif Yang Terdaftar di Bursa Efek Indonesia. Jurnal Kajian Manajemen dan Wirausaha. Vol. 2 No. 01 (2013). 